\title{
The Impact of Communication Technology and Social Media on Intergenerational Relationships between Older Individuals and Their Adult Children in Bangkok
}

\author{
Marie-Helene Thomas (มารีเอแลนน์ โธมัส) \\ Ph.D. in Thai Studies, Faculty of Arts, Chulalongkorn University, \\ Bangkok, Thailand \\ mariethomas@mac.com
}

\begin{abstract}
Modernisation theory (Cowgill and Holmes 1972) argues that older people in modern societies are less respected and valued as a result of technological innovations. To understand the impact of communication technology and social media on Thai society, this research studies the transformations in communication, interaction and overall connectedness between older people and their adult children. In addition, it examines what elements have shifted due to the introduction and use of the smart phone and its accompanying instant messaging and social media applications such as Line and Facebook. The data demonstrates various positive and negative impacts on the intergenerational relationship between older parents and their child cohorts. Crucially, countless examples and arguments from the respondents suggest that the use of these new tools of communication has a very real and demonstrable impact, from providing a space for family members to express their emotions to being the culprit that divides the family unit.
\end{abstract}

\section{Keywords}

ageing - communication technology - social media - intergenerational relationships - successful ageing 
บทคัดย่อ

ผลกระทบของเทคโนโลยีการสื่อสารและสื่อสังคมต่อความสัมพันธ์ระหว่างวัยใน กรุงเทพมหานคร

ทฤษฎีภาวะทันสมัย (Cowgill and Holmes 1972) กล่าวว่าผู้สูงวัยในสังคมยุคใหม่ ได้รับความ เคารพนับถือและมีคุณค่าต่อบุตรหลานน้อยลง เนื่องจากนวัตกรรมทางเทคโนโลยี เพื่อทำความ เข้าใจบทบาทของเทคโนโลยีการสื่อสารและสื่อสังคมบทความนี้จึงมุ่งศึกษาการเปลี่ยนรูปของการ สื่อสาร และปฏิสัมพันธ์และความความเชื่อมโยงระหว่างผู้สูงอายุและผู้ใหญ่ซึ่งเป็นบุตร รวมทั้ง ศึกษาว่ามีองค์ประกอบใดที่เปลี่ยนไปเนื่องจากการใช้เทคโนโลยีสื่อสังคม เช่น โทรศัพท์สมาร์ท โฟน และแอพพลิเคชั่นประเภทสื่อสังคม เช่น ไลน์และเฟซบุ๊ก ข้อมูลที่ได้จากการสำรวจแสดงถึง ผลกระทบทั้งในแง่บวกและลบที่มีต่อความสัมพันธ์ระหว่างคนต่างวัย คือพ่อแม่สูงวัยและผู้ใหญ่ ซึ่งเป็นบุตร ที่สำคัญ ผลการสำรวจพบข้อโต้แย้งจำนวนมากที่ได้จากกลุ่มตัวอย่าง ชี้ให้เห็นว่าการ ใช้เครื่องมือสื่อสารสมัยใหม่นั้นส่งผลกระทบที่เห็นได้ชัดเจน ตั้งแต่การที่ทำให้สมาชิกใน ครอบครัวมีพื้นที่แสดงออกถึงอารมณ์ความรู้สึกมากขึ้น ไปจนถึงการเป็นเหตุให้ครอบครัว แตกแยก

\section{Introduction}

The topic of ageing should be of interest to us all since it is one of the rare topics that is relevant to every single human being. It is a process which we undergo every day and which we are undergoing in fact, as we speak. Part of the study on ageing is to understand how it feels and what it means to continue to be the same person, with the same identity, but within different stages of the body and playing different roles in society. Once a society is affected by the ageing phenomenon, attention is immediately paid to finding solutions in the area of social welfare. The shrinking labour force means a decrease in the ratio of taxpayers to a retiree, which is naturally a burden on state finances. Of course, this is a crucial concern and programmes and policies must be introduced in order to cope with these shifts and provide the elderly population with a sufficient pension and health care plan. Another aspect of this reality, which is equally important but not as widely discussed, is the living condition of the elderly population on a social and psychological level. As people live longer, not only do they require more financial assistance but there are also the challenges of living and ageing successfully in an ever-changing world. Not only are these individuals faced with the widening age gap between them and their family members but they may be exposed to discriminatory attitudes such as ageism, not to mention coping with the impact of modernisation, which despite all its benefits may be creating a divide between the generations. 


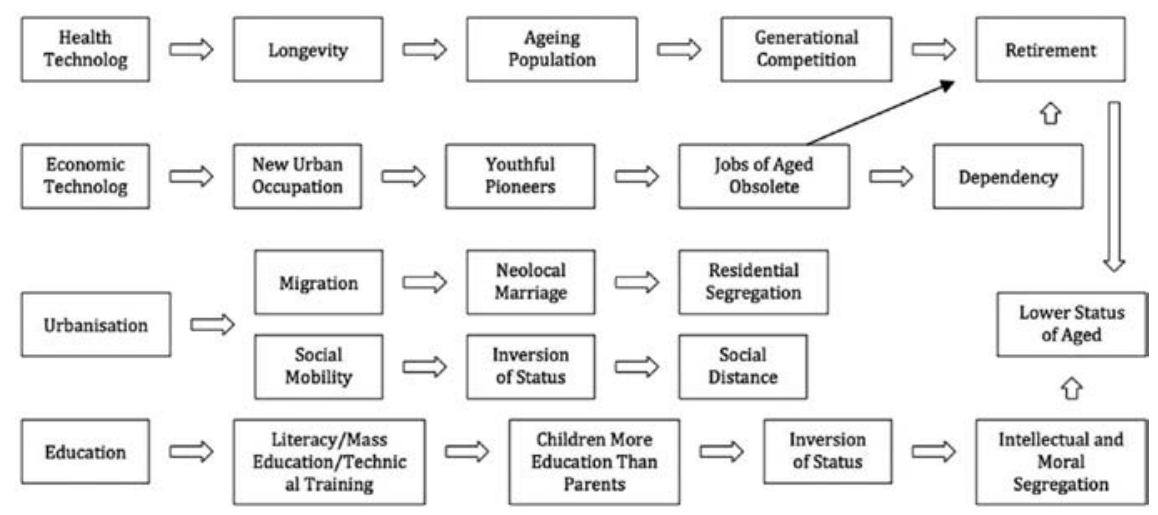

FIGURE 1 Modernisation Theory Flow Chart

The modernisation theory, put forth by Cowgill and Holmes', argues that the value of and respect for older people in society decreases as the nation undergoes the process of modernisation (Cowgill and Holmes 1972). Below is a flow chart that outlines the aspects of modernisation as argued by these two theorists.

According to this theory, the introduction of technology through modernity is the main culprit that affects the ageing population. Two events that significantly shifted attitudes towards older people were the invention of the printing press and the industrial revolution. In the past, older individuals were valued as being the village historians because they had knowledge of and held the key to the past, which they then passed on to younger generations. However, the printing press allowed the culture, history and tradition of a society to be recounted through the form of books, which in turn decreased the contribution, status and value of the older population. The industrial revolution created job opportunities that require the mobility of family units and, of course, older people are not as mobile. Additionally, many jobs required manual labour that was more suited for the young and strong workers. In the industrial revolution, experience made way for adaptability with changing technology, out with the old and in with the new (Nelson 2005). Cowgill and Holmes conducted research on 15 societies undergoing 'development' and discovered that the concept and definition of old age is relative to the degree of modernisation that a particular society has undergone. Modernised societies have a higher proportion of older people as a result of the reduction of birth rates and the increase in lifespan due to technological advances. On average, $3 \%$ of the total population of pre-industrial societies were over the age of 65 while in modern societies, $13 \%$ are. Sanitation, medical diagnostic skills and preventative 
medicine change the vital statistics of a population (Holmes and Holmes 1995). However, life-extending medical advances may be a mixed-blessing for the older population because, in the past, if they were alive it was because of their own strength whereas in modern societies they are often kept alive by modern medicine. Mead argues that in modern societies,

We are now developing a generation which is over-burdened with the care of old people who no longer have any relationship to the rest of the world, who are using up family funds, hospital beds and social resources (Holmes and Holmes 1995, 270).

The modernisation theory suggests that societies that are modernising favour the young. In the Renaissance, old age was respected and seen as the most desirable period of life filled with wisdom and experience (Bond et al. 1993). In societies rich in ceremonial and religious rituals, older people held positions of responsibility and authority. Since they had lived a long life, they acted as the mediator between this world and the supernatural world. While the aged had a greater advantage in more stable pre-industrial societies, in complex consumer societies, the information and knowledge held by older people become obsolete causing their social participation to decline, thus leading to loss of family and social status (Cowgill and Holmes 1972). While youth and innovation are celebrated, the skills and knowledge of older generations are rendered redundant (Bond et al. 1993). In nuclear families, older people lose their decision-making function and authority. Therefore, older individuals are less likely to maintain leadership roles in modern societies. Most older family members are subject to prejudice and pressure to relinquish leadership roles to those who are younger (Cowgill and Holmes 1972).

According to the modernisation theory, it is the changes brought about by modernisation, namely the introduction of technological innovations, that have resulted in the increasing divide between older individual and younger generations in society.

\subsection{Thailand}

Thailand is the second most advanced ageing population in Southeast Asia, after Singapore. The main reasons have been attributed to the substantial increase in life expectancy from the 1950 s and the dramatic fall in fertility rates since the 1960 s. This age-structure shift in the country is foreseen to have three significant implications: there will be fewer adults for each elderly person; a widening gap in the differences between generations in their educational level, occupational experience and attitudes; and a greater demand for health care 
and social services from the elderly population (Arnold 1992). Another phenomenon that is prevalent in Thai society today is that an increasing number of women are getting married after the normal reproductive age (44) or never getting married at all. This is a short-term solution for the ageing phenomenon because single people are more likely to live with their elderly parents, but when they themselves age they will not have any children to care for them (Hayami, Koizumi, Songsamphan, and Tosakul 2012).

The cellphone and personal computer gained popularity in Bangkok during the early 2000 s and since then the number of users of communication technology and social media has increased annually. According to the Information and Communication Technology Survey in Households, in 2013, out of the 63.3 million people in Thailand aged 6 or above, 22.2 million (35\%) were computer users, 18.3 million $(28.9 \%)$ were Internet users and 46.4 million $(73.3 \%)$ were mobile phone users. It is not surprising that Bangkok was the city with the highest percentage of use for these technological advances, whereby $53.3 \%$ of city dwellers were computer users, $48.8 \%$ Internet users and $85 \%$ mobile phone users. The study also revealed to what extent each age group used these innovations. Out of the city's population, the Internet was used by $54.1 \%$ of children (6-14), 58.4\% of young adults (15-24), 33.5\% of adults $\left(25^{-}-34\right), 18.7 \%$ middle aged adults (35-49) and only $6.6 \%$ of old adults $\left(50^{+}\right)$. Interesting, over a five-year span (2009-2013), the last age group, those of 50 or more had the lowest increase of user percentage of only $2.6 \%$, while other age groups had a minimum increase of $6 \%$ (National Statistical Office 2013). On the other hand, however, when focusing on the frequency at which these individuals were using the Internet the result was very interesting. Of the children (6-14) who used the Internet, $25 \%$ were using it daily, of the young adults $\left(15^{-24}\right), 44.6 \%$ were using it daily, of the adults $\left(25^{-34}\right), 64.4 \%$ were using it daily, of the middle aged adults $(35-49) 62.3 \%$ were using it daily and of the old adults $\left(5^{\circ+}\right)$, $55.5 \%$ were using it daily (National Statistical Office 2013). Based on these findings it may be concluded that although a small percentage of old adults use the Internet, only $6.6 \%$, more than half of those that do use it, are using it every day. This frequency rate is the highest in the adults and the middle-aged adults.

The survey also showed that $58.6 \%$ of those that used the Internet were using it for social networking sites. The most popular Social Networking Site in Thailand is Facebook ( $26 \%$ of the total population in the country use this site), which was created by a group of students at Harvard as a means to keep Harvard students connected, then it branched out to other Ivy League universities then eventually allowing the public to create an account. In Thailand today, $87 \%$ of social media users are on Facebook. While Line, which has $66 \%$ of total users, has been voted the most favoured instant messaging platform. Studies 
show that, on average, Thai Internet users spend more than 3 hours a day on their mobile phones, mainly on social networking sites (National Statistical Office 2013). According to these findings, it can be concluded that communication technology and social media play a big role in the social lives of people living in Thailand.

\section{$2 \quad$ Data Results}

This section discusses the data findings collected from $5^{8}$ participants, 30 older individuals and their adult child counterpart through semi-structured interviews. The older people, ages 6o-69, were randomly selected from three elderly people's associations in Bangkok: Khlongtoei, Nonthaburi and Lumpini.

All of the thirty participants had mobile phones and knew how to use them for making and receiving calls. Only one participant from the Duang Prateep Group had a smart phone and knew how to use Line, Facebook or any other instant messaging or social media tools, while eight, from each of the Nonthaburi and Lumpini Group, were actively using these technological innovations.

The interview participants were asked several questions in order to understand from what aspects tools such as the smartphone and Line or Facebook affected the relationship between them and their adult children. The result shows that there are numerous impacts that occur, both positive and negative, from the introduction of these tools into their lives.

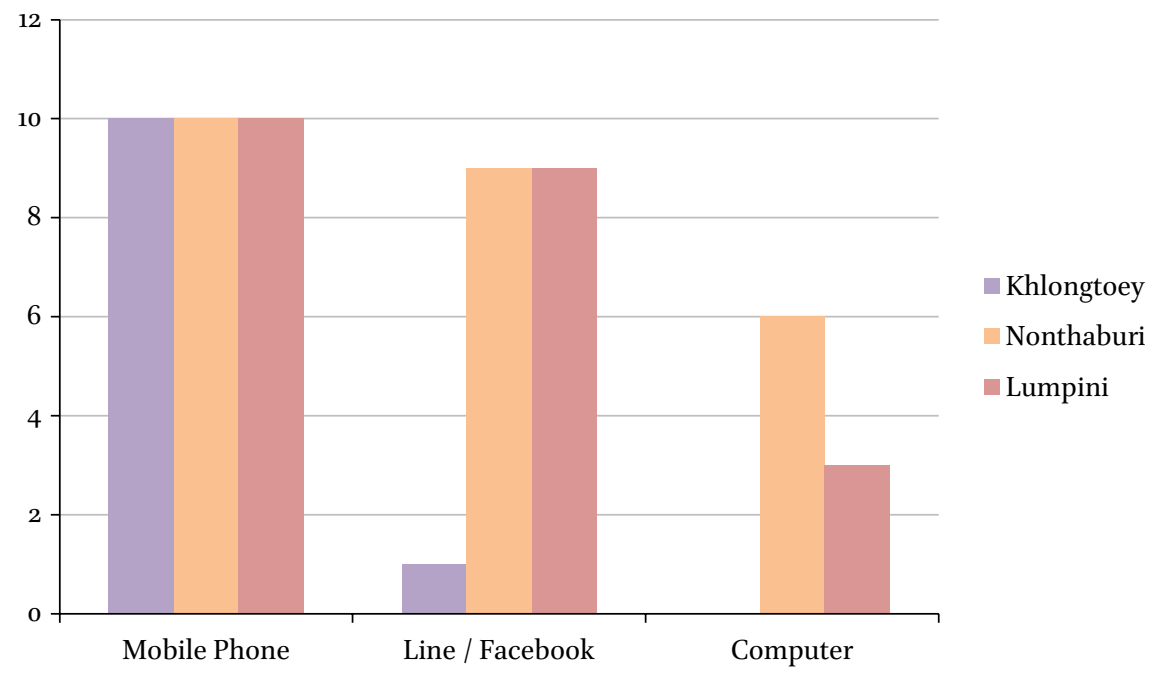

Figure 2 Older Persons Use of Communication Technology 


\subsection{Frequency of Interactions and Activities Shared}

The first positive impact, one that was prevalent in almost every family, is that these tools allow older individuals to stay in touch with their children more efficiently and economically, especially in family members who do not live in the same country.

One woman claims that Line has really improved her relationship with her mother because it allows for frequent contact.

Oh, our relationship has really improved, like so much better now than before. Since I live at the condo and didn't go home often, she used to call me when I was in class and we would miss each other on the phone, we used to talk like once or twice per week but Line really makes us communicate more, sometimes there's nothing to say but we just want to send things to show that we are doing well and miss each other, I think Line allows us to do that. It makes us send funny things to each other, stuff that is meaningless (Daughter, 31, Nonthaburi).

However, the participants said that the use of mobile phones or social media applications as a tool for communication comes with drawbacks, namely in the richness of the communication. Sending text messages several times a day conveys that your family is thinking of you but the danger is that we may believe these actions are enough. Merely getting in touch to let the other person know they are in our thoughts is a nice gesture but people should not overlook the necessity for speaking over the phone or meeting face-to-face as it can strengthen the relationship in ways that virtual communication cannot.

Another factor of Line and Facebook that is frequently mentioned is the fact that it is free-of-charge. This allows family members to message each other or call each other as much as they want without having to worry about the cost per minute as with normal calling packages.

Not only does Line play a role in the relationship between family members when they are apart but these tools also impact how time is spent together. The majority of the parents who were interviewed claim that they realise that family time should be spent without the use of technology and therefore make it a rule of the family not to use mobile phones at the table, since most of the shared time is around meals.

For a few family members, they claim that their family members often use their mobile phones when they are together and that it affects their relationship negatively because they do not really listen to pay attention to one another. 
Sometimes it affects my relationship with my family because I am with my parents but I chat on the phone too much sometimes I know that. But if we can find a balance then life can be very good from using it; it depends on people and how they use it (Daughter, 33, Nonthaburi).

She works on the mobile telephone so when we are together and I say something she doesn't always listen because she's working off her phone (Mother, 63, Lumpini).

Interestingly, most of such complaints were from adult children.

There was a period when my mom was really addicted to a Korean series on the phone and she would just watch it endlessly all alone. If she was not watching it, she would come and talk and play with us (Daughter, 43, Lumpini).

My mom is very addicted to Line and Facebook, she will stalk people friends and family and so she will play on it when we are together; news or what friends send (Son, 36 , Lumpini).

On the other hand, some individuals claim that the use of mobile phones actually facilitates the time spent with one another because it gives them things to do, such as watching funny videos together or reading interesting news which they can discuss with each other.

Yes, we use our phones together. In the past we didn't know what to talk about but now we look at news or clips on YouTube or on Line and we find subjects to talk about from that' (Daughter, 33, Nonthaburi).

Yes, we both use it. We play games or chat with people especially if we are waiting for food and having nothing to talk about but I don't mind. None of us minds when that happens (Mother, 6o, Lumpini).

These responses show that while the majority of participants prefer to spend time together without the use of mobile phones because, according to them, it divides the family, some families have found mobile phones and their applications useful in bringing the family members together because they contain interesting things that can be shared amongst the group. Another theme that was recurrent in the interview is how these technological tools facilitates 
the growth of the relationship between older individuals and their adult children because it allows the children to teach their parents how to use these new tools. Almost every elderly participant, the ones who are currently using these tools and also those who are not, claim that is it their children who suggested they use them. For most of them, it was their children who purchased the smart phones for them and taught them how to use them. This creates an opportunity for the children to pass on knowledge to their parents, which for many is an ongoing thing because parents continuously ask for help in how to use these tools. This exchange in service is an opportunity for the relationship of the two family members to grow and creates a shared platform of interest.

There is no doubt that the mobile phone and applications such as Line and Facebook increase the frequency with which the family members communicate, especially with the ease with which a text message can be sent, with just one click. The downside is that, as several respondents have pointed out, deep and rich conversations such as a long phone call have now often been replaced with less meaningful messages throughout the day. Furthermore, the quality of the time spent together is debatable because while some respondents claim that these tools allow for quality time to be shared between the family members, such as learning how to use the tool or sharing funny clips online, several mentioned that their family members spend too much time playing on their technological devices instead of spending quality time together.

\subsection{Providing Assistance to One Another}

Several participants reported that, since the use of communication technology allows family members to stay in touch more quickly, this allows for convenience and efficiency in reporting an up-to-date status. This is especially easy thanks to the function in the Line application which allows for groups to be created as it allows for news to be spread to multiple recipients at once. This is beneficial to the relationship as it allows for family members effectively to provide assistance to each other.

It is easier to know about emergencies, for instance when someone gets sick, they can easily call to let me know and also check up on me (Father, 66, Khlongtoei).

I think it's good. When I am sick and all alone, I will send a message to my group and everyone will send me food or flowers or come visit. It makes spreading news about our well-being easier and we feel closer. Line makes 
us more aware of problems such as what my dad or mom are facing at any given time (Daughter, 36, Nonthaburi).

According to these women, a mother and a daughter, the use of mobile phones and Line or Facebook, allows them to share their status with the significant people in their lives. This seems to be especially useful when they are feeling under the weather as their family members can easily provide care and assistance once they are quickly informed via Line.

Well it makes it easier for us to care for each other, I can ask what she is doing and get news from her more than before. We connect with each other more often than before. At least if we don't have time, I can text her to ask if she has eaten or what she's up to. This is emotional care which is important (Daughter, 35, Lumpini).

Even in day-to-day events such as finding out whether their family members have eaten dinner is facilitated by the use of Line. It provides a quick and easy method to check up on what they need.

Another aspect of Line and Facebook that several participants referred to is the non-direct forms of communication. Line and Facebook allow for status update and profile changes which, although, not directed at any specific person permit their family members to know what they are up to.

It is a good platform to share. In the past when we didn't have Line, it was harder to share news and updates. I think it has definitely facilitated the way we share information with each other and aids in how we keep connected throughout the day. I see it as a positive impact on our relationship. I always know what she's doing (Mother, 63, Nonthaburi).

This way of communication is unique to social media tools because it has transformed the traditional two-way communication to a one-way mode. Face-to-face communication and telephone calls have always been a two-way communication, which means that when one person speaks, they wish to get a response from the other party. This form of communication requires active engagement and participation. However, Line and Facebook allow a platform for individuals to share updates and news without the need to receive a response or feedback. This allows family members to see what their counterparts are up to, where they are and what they are doing, without having to actively engage. 
According to the respondents, the use of mobile phones and Line allows the family members to provide assistance to one another more easily because they can share news and update one another throughout the day. When older parents need something, they can quickly inform their children who can then meet their needs. Data shows that when older individuals get sick and need to go to hospital, it is their children who normally take them. Through the use of communication technology parents can better inform their children if they need to be taken to hospital. This facilitates immediate assistance.

\subsection{Expressing Sentiments and Diffusing Tension}

Another positive impact that was frequently discussed by both the older parents and their adult children is that texting allows family members to communicate with each other better because sometimes sending text messages is easier than speaking.

I think technology has helped a lot, especially stickers. My son doesn't express himself a lot, not like my daughter. Since we started using Line to talk, I feel it brings us closer because we don't need to say anything; he sends me stickers just to tell me he misses me and I do the same. It is really good for our relationship (Mother, 65, Lumpini).

For this mother, her relationship with her son improved after they started using Line because it allows them to communicate non-verbally. Although faceto-face communication is beneficial in several ways such as in avoiding misunderstandings or allowing for a richer communication experience, some people, who may not be comfortable expressing their emotions verbally, prefer to do so via texting. For these people, the use of social media applications impacts upon their relationship with their family members in a significant way because it allows them to be more expressive and share positive sentiments more easily. This is especially true with the use of stickers, which was a recurring theme, which many participants mentioned as being exceptionally useful in communicating since they allow for emotions to be exchanged without having to use words.

Sometimes I have to leave for work and on the way there I will type to her and send explanations of how I feel or why I behaved the way I did, and I find it really aids our relationship. Some things are difficult to say face to face, or if I say she doesn't listen; through typing she listens more (Daughter, 32, Nonthaburi). 
These sentiments are shared by a mother who claims that her daughter is more willing to listen to what she has to say when she uses Line as the platform for expression.

I will use Line to explain things because when I say stuff to her to her face, she gets bored and doesn't want to listen but when I type it in Line, for some reason she is more willing to read it. Never resolved via Line No, never. We will use it to explain ourselves but to clear the air we need to talk on the phone or face to face. Usually she calls me to resolve issues (Mother, 6o, Lumpini).

According to this woman, Line allows her to filter her emotions because when she messages her daughter after an argument, her emotions, such as the anger in her voice, will be concealed. Often we are upset and we may say things that we regret later if the object of our frustration is standing right in front of us. However, when we use tools such as text messaging to express our anger the other party does not receive the full force of our displeasure.

It's good for fights, I use it all the time, I will type to explain myself. It makes me feel more comfortable than talking directly but sometimes there will be miscommunication via Line. But I am not very good at expressing myself directly and it's easier for me to take my time to express myself through text messages. So, Line helps a lot (Daughter, 38, Lumpini).

Again, for this woman, Line enables her and her mother to get over fights more easily because it provides a platform that isn't as direct as face-to-face, but she mentions, the downside is that sometimes there may be miscommunication.

The use of Line to diffuse tension or mend hurt feelings after a fight was mentioned multiple times. It seems this mode of communication, one that allows a non-confrontational way of expressing one's feelings, is beneficial. Sending messages to each other after a fight allows the other party to read the message at their own pace and let the content sink in without having to reply immediately. This is especially useful for family members who are hotheaded or tend to communicate without a filter as texting their thoughts eliminates the anger or discontent which would have been prevalent in their tone of voice.

\subsection{Bridging the Generation Gap}

According the research findings, a recurring theme that several participants mentioned is how technology allows adult children and their older parents to 
have more similar views because it is a tool enabling older parents to keep up with current trends. As opposed to being a tool that divides the generations, the use of technological tools such as Google or Facebook allows older individuals to keep up-to-date with their children.

I think that technology has brought me and my daughter closer. We have similar education and understand things more than my mother and me. My mother doesn't even read. She is a good mother but she didn't go to school or get educated so her world view and mine are very different but my upbringing was similar to my daughters so we are alike in that way (Mother, 62, Nonthaburi).

This older woman claims that her relationship with her daughter is much better than the relationship she had with her mother when she was younger because technology has allowed her and her daughter to share similar ways of thinking. As for this man, he believes that if used correctly and with an openmind, technology can give elderly people a lot more knowledge.

I think that technology actually gives more knowledge to older people. If they are willing to get on board and learn how to use it then they end up having even more knowledge than before. It benefits elderly people too. Like me, I get so much information about how to grow bananas or other fruits from the Internet (Father, 69, Nonthaburi).

This daughter believes that the Internet allows her mother to gain new knowledge which she then shares with her children.

I will get information and knowledge and share it with her but mostly it is her taking care of me. She will read more contents so she will share knowledge about health with me (Daughter, 31, Nonthaburi).

Another woman claimed that her father understands that we live in a different world so in order to maintain a close relationship with his children, he makes an effort to keep evolving and learning.

He is always learning new things. He tries hard to come into our world and share our interests which means we can share similar hobbies (Daughter, 32, Lumpini). 
Another older person claimed that technology allows him to better understand the world around him and what his daughter is going through. Since the world today is very different from the one he was raised in, technology allows him to find information and search for current trends so that he can better give advice to his daughter.

I think I understand $60 \%$ of her life. I think it is because I follow the news and stay informed with the world today so I am aware of what's going on. I have lived a long life and understand things (Father, 61, Lumpini).

Not only does communication technology allow children to ask for advice more easily, several participants claim that, thanks to the Internet, they have knowledge that is more relevant to their children's lives. Since there is roughly a 30-year gap between the older individuals and their adult children, this means that the parents grew up in a time that was vastly different from the world today. For this reason, the children do not always seek advice from their parents because they feel they are the experts in the current world we are living in. According to the respondents, the use of communication technology bridges this gap because older parents can use it to gain up-to-date knowledge about today's current trends and affairs in order to better understand the very different world and problems their children may be facing.

Analysis

The modernisation theory argues that the value and contribution of older people decreases as a society undergoes modernisation through the introduction of technological advances. However, results from this research suggest the opposite; that older people feel more relevant and have improved relationships with their adult children thanks to such technological advances.

Because of the information that older people are able to access via these tools they are able to share knowledge with their family members allowing them to contribute to the family unit. On the other hand, the younger cohorts also share information with the older people allowing for interaction and more meaningful meal times. Furthermore, communication technology impacts the ways in which the family members associate with one another because it provides an opportunity for the adult children to teach their elderly parents how to use these tools. The role of teacher, which is usually granted to the 
parent, has been transferred to the children and this act of exchanging information and learning can be a very enriching to the relationship. Even though there were several complaints regarding the overuse of mobile phones during meal times, it must be noted that most complaints were from the children, meaning that the older people are the ones more addicted.

Even though the participants in the Khlongtoei group are not active users of Line and Facebook, they still expressed their appreciation for the simple use of the mobile phone which allows them to make calls and receive calls easily. The majority of older people expressed the view that mobile phones allow their children to take better care of them because they can easily update their family members if they require assistance. This is extremely beneficial to older people's well-being because rather than feeling neglected in old age, technology allows their family members to provide constant care and attention to them, increasing their sense of value.

Another positive aspect that communication technology such as Line contributes to the intergenerational relationship between older individuals and their children is that it allows the two family members to express loving sentiments. Countless research has shown that the relationships that older people have with their family members is a main contributor in whether or not they will age successfully; therefore, this impact of communication technology is perhaps the most important one yet. According to the participants in the study, Line allows family members to exchange positive sentiments more comfortably because, for the majority of the interviewees, showing affection face-toface is not something they are familiar with. For participants who are not comfortable expressing their sentiments face-to-face, Line acts as a platform to share their thoughts and feelings. Line allows older people to feel more loved by their children because of the stickers and the affectionate words that their children can easily send to them. Line also assists in diffusing tension when conflicts occur because it creates a filtering system for their negative emotions so that the family members do not regret what they say at a later time. For some, apologies are much more easily expressed using text messages because their family members are more willing to listen. This is especially true with the use of stickers because it allows for a non-verbal form of communication that gets the point across. This is a vital contribution of Line to the family unit because disagreements can cause serious damage to the quality of relationships.

This research has shown that, contrary to the arguments of the modernisation theory, communication technology actually bridges the generation gap between older people and their younger family members. The modernisation theory argues specifically that technology introduced through modernisation 
renders the knowledge of older people obsolete. While it is true that adult children prefer the Internet to obtain knowledge, in reality the older people are also doing the same thing. This results in older people being able to understand the world around them much more clearly and equipped with information to give advice to their children, bridging the generation gap. Therefore, these technological tools are allowing older people to make more contribution within their family unit thus elevating their sense of value and belonging.

In conclusion, according to the results collected from this study, it appears that communication technology assists older individuals to age more successfully since regular interaction with friends and family is highly crucial in maintaining a sense of belonging. Not only do these tools provide older people with opportunities to engage in conversation and communication with their children but through the use of these tools older individuals are able to learn about hobbies or other things of interest, which is especially important given the fact that most of them have a lot more free time once retired. It is apparent that these tools offer a sense of empowerment to older people because it allows them to be independent and able to search for information and share knowledge. Provided that communication technology and social media tools are used in addition to existing methods of communication, as opposed to replacing face-to-face interactions, the advantages are phenomenal in enhancing the quality of relationships.

\section{References}

Arnold, Edward. 1992. Ageing in East and Southeast Asia. Routledge.

Bond, John, Peter Coleman, and Sheila Peace. 1993. Ageing in Society: An Introduction to Social Gerontology. SAGE Publications.

Bond, John, Robert Briggs, and Peter Coleman. 1993. "The Study of Ageing." In Ageing in Society: An Introduction to Social Gerontology, 19-52. SAG E Publications.

Hayami, Yoko, Juno Koizumi, Chalidaporn Songsamphan, and Ratana Tosakul (eds). 2012. The Family in Flux in Southeast Asia: Institution, Ideology, Practice. Kyoto: Kyoto University Press.

Holmes, Ellen R., and Lowell D. Holmes. 1995. Other Cultures, Elder Years. London: SAGE Publications.

Cowgill, Donald O., and Lowell D. Holmes. 1972. Aging and Modernization. New York: Appleton-Century-Crofts.

Nelson, Todd. 2005. "Ageism: Prejudices Against Our Feared Future Self." Journal of Social Issues 61 (2): 207-221. 


\section{Reports}

The 2013 Information and Communication Technology Survey in the Household National Statistical Office, Ministry of Information and Communication Technology 2013. 